\title{
Problem Faced by Students in Direct Discussion Session of Speaking Class
}

\author{
Abdilah Bagus Ramadhan Putra Setiawan \\ UIN Syarif Hidayatullah Jakarta \\ abdillah.bagus19@mhs.uintjkt.ac.id \\ Novia Syifaputri Ramadhan \\ UIN Syarif Hidayatullah Jakarta \\ novia.syifaputrir19@mhs.uinjkt.ac.id \\ Tiara Nuradilla \\ UIN Syarif Hidayatullah Jakarta \\ tiara.nuradilla19@mhs.uinjkt.ac.id
}

\begin{abstract}
Many students found that actively participating in direct discussion sessions of speaking class is hard. There are various problems that they felt whenever they wanted to speak in the class. Thus, this study is aimed to discover what are the major problems encountered by the students in a speaking class which cause low participation during the discussion. This study uses survey research and uses a questionnaire as the instrument. The subjects of this study were 34 students of the English Education Department in the $5^{\text {th }}$ Semester at UIN Syarif Hidayatullah Jakarta. The result of the data analysis shows that there are a variety of problems that students feel when they were in the Speaking class. The issues are related to their lack of confidence, bravery, anxiety, and lack of motivation.
\end{abstract}

Keywords: Problem in Speaking Class, Direct Discussion, English Language Teaching

\section{INTRODUCTION}

Speaking is the most common way that is used by people to do the communicate and share some thoughts with each other. In the speaking class of the English Education Department in UIN Syarif Hidayatullah Jakarta, specifically in the discussion session, students are required to actively speak on the issues that are being explored.

The concerns that were discovered in the direct discussion session of the Speaking class were analyzed in this study. The researchers gathered data by creating a questionnaire regarding some of the issues that students might encounter in Speaking class. The problems encountered by the students in the English language education department in speaking class, cover self-confidence, anxiety, afraid of being criticized, the lack of appropriate vocabulary, the lack of grammar mastery, the lack of correct pronunciation, the lack of input of English outside the class, the lack of confidence and the lack of English-speaking curriculum development (Rumiyati \& Seftika, 2018). Those things cause low participation during the discussion. 


\section{VOL. 03 NO. 02 , DECEMBER 2021}

Referring to the background, this study aims to investigate the problems encountered by students during the direct discussion session of the speaking class. The following are the research questions:

1. What are the problems faced by students in direct discussion of speaking class?

2. What is the reason behind students' problems in direct discussion of speaking class?

Direct discussion is a discussion organized by the teacher to keep communication on the correct path whilst also boosting learners to take part. Based on (Tucker, 2016), the term "direct discussion" refers to a discussion that is guided by the presenter or teacher in order to keep the conversation on track while encouraging learners to engage. According to (Gallagher, Tiffany; Ciampa, 2020), in a discussion, the teacher's responsibility is to guide the students and encourage them to participate as much as possible. Despite the fact that the teacher has stimulated pupils to participate in the conversation, there are still a few students who are confident enough to voice.

Based on the previous studies, speaking was considered as a skill of communication in class, students are supposed to be able to participate in the class. Students are required to share some opinions and thoughts in the speaking class, so they can participate in direct discussion in the class. According to (N, 2013) direct discussion is a discussion between a group of people where one person keeps the discussion on the right track. In an educational setting, for example, a professor would provide curriculum-directed focus based on experience, while the students would contribute varied perspectives and broad-ranging information from their research.

Several studies have investigated the issue of students' problems in direct discussion of speaking class. Anxiety may be one of the factors that make the student feel reluctant to speak in the class. As in the second study conducted by (Rumiyati \& Seftika, 2018) entitled "Anxiety of Speaking English in Foreign Language (EFL) Class", the finding shows that three aspects of foreign language anxiety have a significant impact on students' teaching and learning processes, particularly in the area of speaking. Communication anxiety, test anxiety, and the fear of a critical evaluation were the main causes of the student's speaking anxiety in this situation.

Other studies were also conducted by (Rustandi, Andi; Mubarok, 2017) about the interaction between students and teachers. The active engagement of student-teacher in the speaking class is reflected by teacher initiation, in which the teacher initiates the students by asking questions, seeking information, and identifying the pupils who will have the next turn to answer. If the topic in the classroom lesson is simple, students will be more likely to participate. In order to fully participate and contribute in a speaking class, students must create their own opportunities and devise a method for learning the language and improving their knowledge. They also need to learn and train the language to boost their motivation to study and speak English.

According to prior research, students experienced a variety of issues in a speaking class discussion, including confidence, nervousness, a lack of grammar, and a fear of making mistakes. As a result, the purpose of this study was to look into the precise cause of students' inability to speak confidently in a class discussion. In order to achieve that, (Abrar et al., 2016) in their study stated that to deal with the issue of not feeling confident to engage in the discussion, teachers can design relevant speaking themes and activities that encourage pupils to speak enthusiastically and comfortably. When students are more excited about a topic, they are more likely to speak without fear or hesitation.

All previous research focused primarily on students' internal factors to communicate in the direct discussion of speaking class. Therefore, this study will investigate whether or not there is an external factor causing student problems during the direct discussion session of speaking class. 
This study's questionnaire addressed several questions concerning students' perceptions of their friends' competency in the direct discussion.

\section{METHOD}

This study is conducted by survey research methodology and used a questionnaire as the only instrument. Survey research is aimed to get data collection commonly with questionnaires and interviews from a group of people (Dillman, 2014). The data were gathered and analyzed using the Likert scale. According to Bahrun (Bahrun et al., 2017), a Likert scale is a scale used to assess a person's or group's attitudes, opinions, and perceptions of social phenomena. The final data is explained descriptively based on the result of the data.

The sample for this study, who were filled in the questionnaire, is a group of people from UIN Syarif Hidayatullah Jakarta majoring in English Education. This group of people consists of 34 students from the fifth semester that have been assured to be attending direct discussion in speaking class before.

In this research, the researcher solely utilized a questionnaire as an instrument. Based on (Dash, 2017), a questionnaire is a set of open-ended or closed-ended queries to which respondents answer. In this study, a questionnaire is needed to find out the major problems faced by students in the direct discussion sessions. In general, the questionnaires consisted of questions related to the problems faced by students in speaking class. There are 9 questions related to self-confidence, 6 questions about bravery, 4 questions about anxiety, and 1 question about self-motivation. The students were asked to fill the questionnaire which was arranged with 20 questions in the form of Likert with the scale five-level, which are 1) Strongly Disagree, 2) Disagree, 3) Neutral, 4) Agree, 5) Strongly Agree.

\section{FINDINGS AND DISCUSSION}

The researchers find out what problems are faced by English education students at UIN Syarif Hidayatullah Jakarta and the two research questions were linked to students' Likert Scale responses. The information gleaned from the questionnaires was analyzed and interpreted. This instrument's results will be presented in the form of tables and percentages., and then will be classified. This category includes issues that students faced in speaking class.

The first problem found from the questionnaire was the participants worried that they will make mistakes, because when they try to answer and they have to express the answer in front of other students and teachers, but turns out that it is wrong, sometimes there are some teachers who directly judge them, so it affects student's mental and makes them reluctant to express their opinions and will feel ashamed of themselves. It is in accordance to the findings by (Damayanti \& Listyani, 2020) that said one of the factors students' speaking anxiety in English speaking class is worried about making mistakes and being ashamed in front of their friends.

While the second problem was, they are not brave enough when they are chosen to appear in front of the class. It is because most students have instilled in themselves fear of being wrong and of being judged, they do not dare to show themselves in class, even though not everything they think is in accordance with the actual situation that would occur. (Wahyuningsih \& Afandi, 2020) 


\section{VOL. 03 NO. 02 , DECEMBER 2021}

also supported this factor. According to their research results, one of the difficulties that students are having is a lack of self-esteem in in English speaking class.

Furthermore, the third problem was students feel that their friends are better in terms of presentation or discussion than themselves because students feel insecure with students who are more competent than them. The reason of their insecurity was because they believe they are unworthy of expressing themselves, so they choose to give opportunities to others who they believe are more competent. When learners engage or carry on a discussion with their fellow students, an interaction takes place. By having a discussion with their friends, student might think that their friends are way better than them and that makes the student feel ashamed to actively participate in the discussion. Most of the time, they only listen to the classroom discussion and do not take an active part by attempting to give their opinions or responses. While actually, (Tiwery \& Souisa, 2019) said that through the active discussion with their friends, students present high enthusiasm in speaking activities in the classroom by taking an active role in presenting their opinions related to the topics and providing relevant insights to their friends' thoughts. They are less-burdened to talk to their friends, rather than talking to the teacher.

The fourth problem was the students are less confident to answer the question from teacher or student because students are afraid of being wrong and being judged by the teacher or other students. The next problem was the students are willing to speak up if other students do so. Because there is a tendency for students to feel embarrassed and afraid, most students wait for one of the brave or confident students to speak up first. When students believe they are capable, they will participate.

The sixth problem, the students will choose to remain silent, even though they can answer the questions at hand. It is because most the students are embarrassed to express their opinions and are worried if their opinions conflict with the teacher or other students.

The seventh problem was they are embarrassed to ask questions with the teacher or friend. And the last problem, was revealed that the participants agree and strongly agree that they talk little or nothing in the speaking class because rather than they have to say because they are embarrassed and don't want to be judged or viewed as stupid for making inappropriate statements.

\section{CONCLUSION AND SUGGESTION}

To conclude the findings of this study, the main issue that students face in Speaking class is a lack of confidence and shyness. They are afraid of making mistakes $\&$ are hesitant to speak in front of the class. They are embarrassed as they believe their other friends are better at speaking in public than they are. According to the results of our questionnaire, it is also shown that the students' confidence will increase once their friends talk. This point is still related to the previous point in which they feel their friends are better than themselves. The reasons why they lack confidence and are afraid to start speaking in front of their peers are because they don't understand the material that is being discussed and they are demotivated.

For further research, the researchers suggest using more instruments in conducting the research. To expand the data, more participants are also suggested. Considering this study only used one instrument which was a questionnaire and there were only 34 participants included. 


\section{REFERENCES}

Abrar, M., Failasofah, F., Fajaryani, N., \& Masbirorotni, M. (2016). EFL Student Teachers' Speaking Anxiety: the Case in One English Teacher Education Program. IJEE (Indonesian Journal of English Education), 3(1), 60-75. https://doi.org/10.15408/ijee.v3i1.3619

Bahrun, S., Alifah, S., \& Mulyono, S. (2017). Rancang Bangun Sistem Informasi Survey Pemasaran dan Penjualan Berbasis Web. Jurnal Transistor Elektro Dan Informatika, 2(2), 81-88. http://jurnal.unissula.ac.id/index.php/EI/article/view/3054

Dash, B. (2017). Methods of Data Collection. Essentials of Nursing Research and Biostatistics, July 2016, 175-175. https://doi.org/10.5005/jp/books/13075_10

Dillman, D. (2014). Internet, Phone, Mail, and Mixed-Mode Surveys: The Tailored Design Method. John Willey \& Sons, Inc.

Gallagher, Tiffany; Ciampa, K. (2020). Teaching Literacy in the Twenty-First Century Classroom (1st ed.). Palgrave Macmillan. https://doi.org/10.1007/978-3-030-47821-6

N, P. (2013). Directed Discussion Method. PsychologyDictionary.Org. https://psychologydictionary.org/directed-discussion-method/

Rumiyati, R., \& Seftika, S. (2018). Anxiety of Speaking English in English Foreign Language (Efl) Class. Journal of English Education, Literature and Linguistics, 1(1), 46-61.

Rustandi, Andi; Mubarok, A. H. (2017). Analysis of IRF (Initiation-Response-Feedback) on Classroom Interaction in EFL Speaking Class. EduLite (Journal of English Education, Literature, and Culture), 2(1), 239-250.

Tucker, R. (2016). Collaboration and Student Engagement in Design Education. https://doi.org/10.4018/978-1-5225-0726-0

Damayanti, M. E., \& Listyani, L. (2020). An Analysis of Students' Speaking Anxiety in Academic Speaking Class. English Language Teaching and Research Journal, 4(July), 152170. https://doi.org/10.37147/eltr.2020.040206

Tiwery, D. S., \& Souisa, T. R. (2019). Inside-Outside Circle as the Way in Building Students' Motivation and Interaction in Speaking Classroom Activities. International Journal of Language Education, 3(1), 33-45. https://doi.org/10.26858/ijole.v1i1.6703

Wahyuningsih, S., \& Afandi, M. (2020). Investigating English Speaking Problems: Implications for Speaking Curriculum Development in Indonesia. European Journal of Educational Research, 9(3), 967-977. https://doi.org/10.12973/EU-JER.9.3.967

\section{APPENDIX}

Table 1. Problems Faced by Student in Speaking Class

\begin{tabular}{|c|l|c|c|c|c|c|c|c|}
\hline No & \multicolumn{1}{|c|}{ Statements } & SD & D & N & A & SA & TS & \% \\
\hline 1 & $\begin{array}{l}\text { I feel confident when I have to present in } \\
\text { front of the class. }\end{array}$ & - & 2 & 9 & 22 & 1 & 130 & $76.47 \%$ \\
\hline 2 & $\begin{array}{l}\text { I will dare to start a conversation if } \\
\text { someone else has started it first. }\end{array}$ & - & 2 & 7 & 23 & 2 & 127 & $74.70 \%$ \\
\hline
\end{tabular}


VOL. 03 NO. 02 , DECEMBER 2021

\begin{tabular}{|c|l|c|c|c|c|c|c|c|}
\hline 3 & $\begin{array}{l}\text { I will choose to remain silent, even though } \\
\text { I can answer the questions at hand. }\end{array}$ & - & 4 & 16 & 12 & 2 & 114 & $67.05 \%$ \\
\hline 4 & $\begin{array}{l}\text { I feel that my friend is better than me when } \\
\text { presenting. }\end{array}$ & - & 1 & 7 & 16 & 10 & 129 & $75.88 \%$ \\
\hline 5 & $\begin{array}{l}\text { I feel confident when I have to answer a } \\
\text { question. }\end{array}$ & - & 2 & 23 & 8 & 1 & 115 & $67.64 \%$ \\
\hline 6 & $\begin{array}{l}\text { When discussing, the opinions I convey are } \\
\text { less interesting. }\end{array}$ & - & 2 & 19 & 11 & 2 & 115 & $67.64 \%$ \\
\hline 7 & $\begin{array}{l}\text { I am confident when expressing opinions in } \\
\text { class. }\end{array}$ & - & 1 & 17 & 15 & 1 & 118 & $69.41 \%$ \\
\hline 8 & $\begin{array}{l}\text { I am not brave enough when I am chosen to } \\
\text { appear in front of the class. }\end{array}$ & - & 3 & 8 & 15 & 8 & 130 & $76.47 \%$ \\
\hline 9 & $\begin{array}{l}\text { I feel confident when explaining the } \\
\text { material in class. }\end{array}$ & - & 2 & 18 & 14 & - & 128 & $75.29 \%$ \\
\hline 10 & $\begin{array}{l}\text { I feel less confident with the answer I } \\
\text { convey. }\end{array}$ & - & 3 & 17 & 12 & 2 & 115 & $67.64 \%$ \\
\hline 11 & $\begin{array}{l}\text { I will spontaneously ask questions when I } \\
\text { do not understand the material. }\end{array}$ & 1 & 2 & 15 & 16 & - & 114 & $67.05 \%$ \\
\hline 12 & $\begin{array}{l}\text { When the teacher asks a question, I } \\
\text { volunteer to answer without being asked. }\end{array}$ & 2 & 9 & 16 & 7 & - & 96 & $56.47 \%$ \\
\hline 13 & $\begin{array}{l}\text { I feel embarrassed when I ask friends or } \\
\text { teachers. }\end{array}$ & 4 & 7 & 15 & 8 & - & 103 & $60.58 \%$ \\
\hline 14 & $\begin{array}{l}\text { I feel capable when I have to deliver } \\
\text { material in front of many people. }\end{array}$ & - & 3 & 9 & 22 & - & 121 & $71.17 \%$ \\
\hline 15 & $\begin{array}{l}\text { I am actively involved in group discussions. } \\
18\end{array}$ & - & 1 & 4 & 25 & 4 & 134 & $78.82 \%$ \\
\hline 16 & $\begin{array}{l}\text { I am worried that I will make mistakes. } \\
\text { I have no motivation to express myself. }\end{array}$ & 1 & 3 & 4 & 15 & 11 & 134 & $78.82 \%$ \\
\hline 17 & $\begin{array}{l}\text { I fear criticism or feel embarrassed. } \\
\text { I nathing to say. }\end{array}$ & 1 & 3 & 10 & 15 & 5 & 117 & $68.82 \%$ \\
\hline
\end{tabular}


VOL. 03 NO. 02 , DECEMBER 2021

\begin{tabular}{l|l}
\hline 20 & I talk little or nothing
\end{tabular}

2

4

6

18

4

120

$70.58 \%$

\section{NOTE:}

SD : Strongly Disagree

D : Disagree

$\mathrm{N} \quad$ : Neutral

A : Agree

SA : Strongly Agree

TS : Total Score

The data from the table were calculated using this formula:

\section{T x Pn}

$\mathrm{T}=$ the total of respondents who selected

Pn $=$ Likert score option

\section{Interpretation of calculation score}

$\mathrm{Y}=$ the highest rating Likert scale multiplied by the number of respondents

$\mathrm{X}=$ the lowest mark Likert scale multiplied by the number of respondents

\section{Index formula $\%=$ Total score/Y x 100}

(https://www.diedit.com/skala-likert/;

Riduwan and Akdon (2009)) 
